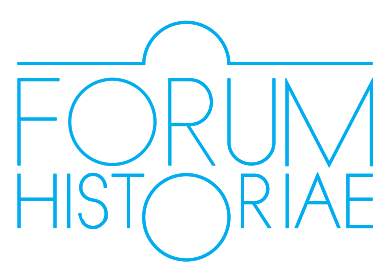

\title{
Vystúpenia z druhej svetovej vojny
}

\author{
Robert Frank
}

\begin{abstract}
:
FRANK, Robert: Exiting World War II.

In his study the author deals with the exiting World War II from several viewpoints. First he analyses the heritage from the exiting World War I, that is those efforts which did not succeed after 1918, but became an inspiration for the post-1945 period, such as the international influence of the United States, the international justice system, the foundation of the UN and European integration. In the second part he focuses on the specifics of the exiting World War II such as the occupation, brutality and the global dimension. To conclude, he puts the exiting World War II into the context of the whole of the duration of the Cold War. Both of the conflicts which preceded and succeeded World War II thus significantly affected its complicated exiting.
\end{abstract}

Keywords: exiting wars, First Wolrd War, World War II, Cold War, European integration

Dojem „vystúpení z vojny“ vypracovali historici za posledných dvanást’ rokov, najmä historici prvej svetovej vojny, medzi ktorých patrí Stéphane Audoin-Rouzeau. Neobmedzuje sa na bývalé „povojnové obdobie“ ani na „následky vojny“, klasické pojmy, ktoré odkazujú na statický prístup k „dôsledkom konfliktov“ z demografického, hospodárskeho, sociálneho, politického a geopolitického hladiska. Ide o dynamickejšie "pochopenie procesu demobilizácie spoločností, armád, štátov a hospodárstiev", analyzovanie konkrétneho spôsobu, akým civilné a vojenské obyvatel'stvo prežíva prechod od vojnového $\mathrm{k}$ mierovému stavu, ${ }^{1}$ opísanie spôsobu, akým spoločnosti vnímajú sociálne, kultúrne, hospodárske, politické, medzinárodné zmeny spôsobené vojnou, ktorá sa skončila. Treba si uvedomit', že vnímanie týchto zmien zas môže pozmenit' ich dosah. Je tiež potrebné zmerat' rozsah a trvanie stôp po vojne - fyzických, morálnych a pamät'ových.

Každý konflikt tak má viacero druhov „vystúpení“, ktorých chronológia je premenlivá. Zvlášt' to platí pre druhú svetovú vojnu. Vystúpenia z nej môžeme postupne datovat' od roku 1945 do 90. rokov, dokonca až po roku 2000. 0 niektorých z nich sa „premýšlalo“ počas samotného konfliktu po zohladnení skúseností z predchádzajúcej vojny. Iné sú vo vztáahu k tejto skúsenosti z rokov 1914 - 1918 autonómne. Ďalšie sú napokon narušené, či dokonca oneskorené vplyvom neskoršieho svetového vývoja, ktorý bol poznačený najmä novým typom vojny, studenou vojnou. To je jedna z typických čŕt vystúpení z druhej svetovej vojny: sú situované medzi dvoma konfliktmi a vplýva na ne tieň vojny 1914 - 1918, pričom zároveň sa prekrývajú so začiatkom americko-sovietskej konfrontácie.

1 FLATEAU, Cosima. Les sorties de guerre. Une introduction. In Les Cahiers Sirice, 2016/3, č. 17. 


\section{Tieň rokov $1914-1924$}

Vystúpenie z druhej svetovej vojny je v mnohých ohladoch vystúpením z prvej svetovej vojny, akoby problémy spôsobené vystúpením zo zrážky z rokov 1914 1918 boli zle vyriešené alebo boli v rokoch 1931 - 1943 spochybnené a riešenie našli vo vyústení konfliktu 1939 - 1945 (alebo 1937 - 1945, ak chronológiu stanovíme podla Ázie, a nie podla Európy). Na toto vystúpenie z vojny sa nazerá na základe ponaučení z rokov 1914 - 1918 a 1919 - 1920.

\section{Nemožnost' návratu k impériám a nové vít'azstvo národných štátov}

Vojnový nacionalizmus talianskeho fašizmu a nemeckého nacizmu bol síce katastrofický, no myšlienka „národa“ nie je po ukončení konfliktu spochybnená. Tretia ríša so svojou zločinnou a krvavou expanziou potvrdila zlý obraz impérií. Deštrukcia Hitlerovej „novej Európy“ sa tiež vo vel'kej miere diala prostredníctvom obnovenia štátov vytvorených alebo znovuvytvorených v rokoch 1918 1920 a prostredníctvom potvrdzovania konca impérií v Európe. Dochádzalo však k určitým úpravám. Pol'sko stratilo svoje východné regióny obývané najmä Nepoliakmi v prospech ZSSR a jeho Bieloruskej a Ukrajinskej republiky; kompenzáciu získalo na západe v Sliezsku a Pomoransku na úkor Nemecka. Boli obnovené zmiešané štáty vzniknuté po prvom svetovom konflikte, akým je Československo, ktoré stratilo Podkarpatskú Rus, a Juhoslávia. Tá sa zmietala v občianskej vojne: Mihailović, srbský monarchista a nacionalista, ktorý chcel z tejto krajiny urobit' "Vel'ké Srbsko", prehral a bol popravený na príkaz Tita, komunistu chorvátskeho a slovinského pôvodu, ktorý mal, naopak, v pláne federálnu republiku vyváženejšiu než medzivojnové královstvo, v ktorom mali Srbi hegemóniu.

Zmluvy z rokov 1919 - 1920 vytvorili nové štáty, no nevyriešili otázku národnostných menšín. V roku 1914 žilo v Európe 60 miliónov obyvatelov pod nadvládou určitej ríše a väčšiny, s ktorou sa nestotožňovali alebo mali problém sa s ňou stotožnit'. V roku 1920 malo 30 miliónov obyvatelov napriek koncu impérií a uplatňovaniu národnostného princípu s cielom zmenit’ európsku geopolitickú konfiguráciu stále postavenie „národnostnej menšiny“. Po roku 1945 došlo k pokusom vyriešit' problém hromadným prestahovaním obyvatel'stva: východní Poliaci boli z území anektovaných ZSSR vytlačení na západ do nového Pol'ska; milióny Nemcov pochádzajúcich z území pričlenených k Pol'sku boli vytlačené do Nemecka rovnako ako sudetskí Nemci, ktorí opustili Čechy. ${ }^{2}$

\section{Váha nemeckej otázky}

Čo urobit' s Nemeckom? Historik Jacques Bainville zahorúca opisoval situáciu po prvom svetovom konflikte a tvrdil, že vítazi sa dopustili vel'kej chyby tým, že zastavili nepriatel'stvo príliš skoro, že nepočúvali maršala Focha, ktorý chcel prekročit' Rýn a tiahnut' na Berlín, aby bolo vít'azstvo úplné a nesporné. Rovnako písal, že bolo vel'mi slabou stránkou Versailleskej zmluvy z roku 1919, ktorá

2 Po prvej svetovej vojne bol jediným príkladom hromadného prest’ahovania obyvatel'stva presun Grékov z Malej Ázie po grécko-tureckej vojne, po ktorom nasledovala výmena medzi Grékmi a Turkami stanovená Lausannskou zmluvou z roku 1923. 
bola výsledkom kompromisu medzi vít’azmi, to, že „nebola dostatočne tvrdá v tom, $v$ čom bola tvrdá, a nebola dostatočne mierna $v$ tom, $v$ čom bola mierna“. Jej tvrdost' ponižovala Nemcov a hrozilo, že ich bude udržiavat' v duchu odplaty; a jej miernost' im dávala prostriedky na odplatu, keby o ňu mali záujem. To napokon spôsobilo znepokojenie Francúzov, ktorí požadovali striktné uplatňovanie zmlúv a dlho aj úplné splatenie reparácií. V rokoch 1943 až 1946 sa Spojenci pustili presne opačnou cestou: na začiatku chceli byt' extrémne tvrdí, aj keby mali neskôr svoje pozície zmiernit'. Na konferencii v Casablance v januári 1943 Američania a Briti rozhodli, že vojna sa môže skončit' len bezpodmienečnou kapituláciou Hitlerovho režimu, s čím Sovieti súhlasili. Spojenci chápali ponaučenie z roku 1919: nacistickému Nemecku treba dat' pocítit', že je porazené, preto boli na začiatku stanovené mimoriadne tvrdé podmienky: úplná okupácia, významná strata území, reparácie najmä v prospech ZSSR. Počas „vystúpenia z vojny“ a v prospech začínajúcej studenej vojny sa však západní okupanti ukázali byt’ zhovievavejší, ked' uprednostnili rekonštrukciu svojich okupačných zón, ako aj vytvorenie demokratickej Nemeckej spolkovej republiky, z ktorej urobili svojho spojenca.

\section{Váha Spojených štátov pri vystúpení z vojny}

Spojené štáty po dvoch svetových konfliktoch výrazne posilnili svoju moc, vplyv a schopnost' rozhodovat'. Po prvej vojne, od roku 1920, sa relatívne stiahli z medzinárodnej scény. Neboli členmi Spoločnosti národov napriek tomu, že ich prezident Woodrow Wilson ju navrhol a podporoval: nepodarilo sa mu dosiahnut', aby Kongres ratifikoval mierové zmluvy obsahujúce články, ktorými bola Spoločnost' národov vytvorená. V postavení najsilnejšej svetovej vel'moci odmietali hrat' túto úlohu Vel'kého, a ako povedal minister zahraničných vecí Charles Evans Hughes v roku 1922, neboli ochotné niest' „bremeno svetového diania“.3 Prispeli tak $\mathrm{k}$ destabilizácii medzinárodného systému v medzivojnovom období a vytvorili v ňom trhlinu, ktorú využil Hitler.

Američania sa po roku 1945, opät’ na základe ponaučenia z vystúpenia z prvej vojny, tentoraz rozhodli zostat' v popredí diania a podiel'at' sa na regulovaní medzinárodných vzt’ahov. Franklin Roosevelt urobil všetko preto, aby Kongres akceptoval jeho projekt Organizácie spojených národov. Krajina prijala úlohu prvej svetovej vel'moci o to viac, že sa rýchlo profilovalo napätie vo vzt’ahu so sovietskym spojencom z obavy, žeby mohol ovládnut' Európu, a z presvedčenia, že je potrebné „krotit““ jeho expanzívne sklony. Z tohto pohl'adu je slávny prejav ministra zahraničných vecí Georgea Marshalla z 5. júna 1947 presným opakom prejavu Charlesa Evansa Hughesa z roku 1922. ${ }^{4}$

\section{Váha práva: Spoločnost' národov, OSN a medzinárodná justícia}

Počas vystupovaní z oboch vojen sa vít'azi usilovali, aby bolo právo a spravodlivost' ústredným bodom medzinárodných vztahov s ciel'om zachovat' mier. Spoločnost'

3 Prejav republikánskeho ministra zahraničných vecí Charlesa Evansa Hughesa v Newhavene (Connecticut) 29. decembra 1922.

4 Prejav demokratického ministra zahraničných vecí Georgea Marshalla na Harvarde 5. júna 1947. 
národov bola bez Spojených štátov napriek niekol'kým krátkodobým úspechom príliš slabá na to, aby mala trvalý úspech. Po roku 1945 sa zdalo, že OSN na tom nebola lepšie: čoskoro bola zablokovaná v dôsledku súperenia dvoch vel'mocí. Stále však existovala, bola referenciou v mnohých oblastiach medzinárodného práva a javila sa byt' platformou na vyjadrenie „globálneho názoru“, či dokonca „medzinárodnej legitimity“, ktorú priznávala (1991) alebo nepriznávala (2003) vojenským zásahom proti diktátorovi ohrozujúcemu mier.

Vítazi chceli aj „spravodlivost“" pre „zodpovedných“ alebo „vojnových zločincov“. Po prvom svetovom konflikte sa im nepodarilo zorganizovat' proces proti Viliamovi II. napriek tomu, že bol upravený v článku 227 Versailleskej zmluvy, lebo Holandsko, do ktorého utiekol, ho odmietlo vydat'. V každom prípade by konfigurácia vtedajšieho práva komplikovala súdne stíhanie cisára. Potom bolo niekol'ko nemeckých vojakov postavených pred súd na základe článku 228 tej istej zmluvy „pre skutky v rozpore s vojnovými zákonmi a zvyklost'ami“: z procesu, ktorý sa začal pred vrchným ríšskym súdom v Lipsku v máji 1921, sa stala fraška. Po druhej svetovej vojne to bolo úplne inak. V norimberskom procese (1945 - 1946) súdili vysokých nacistických hodnostárov, ktorí boli postavení pred medzinárodný súd ustanovený vítazmi nielen za zločiny proti mieru a vojnové zločiny, ale aj za „zločiny proti l'udskosti“ definované a spresnené v priebehu procesu, čo znamenalo začiatok novej právnej éry a posilnenie medzinárodného práva. Tokijský proces (1946 - 1948), v ktorom súdili vysokých japonských vojenských velitelov, mal menší dosah možno preto, že cisár Hiro Hito, ktorého chceli Američania ochránit', doň nebol zahrnutý: ušetrit' cisára znamenalo ušetrit' japonský l'ud; Japonsko sa v dôsledku toho nepustilo do skutočného morálneho prehodnocovania, ktoré Nemci boli ochotní uskutočnit'. Predsa sa však začala nová právna éra. OSN svojimi rezolúciami 94, 95 a 96 z 11. decembra 1946 potvrdila norimberské a tokijské princípy, pričom zároveň spresnila definíciu jedného zo zločinov proti l'udskosti a použila nové slovo, ktoré krátko predtým vytvoril Lemkin, „genocída“: „odopretie práva na existenciu celým skupinám osôb rovnako ako zabitie je odopretie práva na existenciu jednotlivcovi“. ${ }^{5}$ Následne rezolúcia 260 A (III) schválená 9. decembra 1948, v predvečer prijatia Všeobecnej deklarácie l’udských práv, stanovila vytvorenie Medzinárodného trestného súdu, ktorý má súdit' osoby obžalované z genocídy. Tento MTS uvidel svetlo sveta až v roku 1998. Vystúpením z druhej svetovej vojny sa však otvorilo pole možností a začala sa revolúcia v medzinárodnom práve: mohlo vyjst' zo svojho štátneho a medzištátneho rámca a stat' sa nadnárodným a celosvetovým, ked' išlo o stíhanie extrémnych trestných činov.

V oblasti medzinárodného humanitárneho práva boli pokroky dosiahnuté vytvorením Červeného kríža a Ženevskej konvencie z roku 1864 a následne Ženevskej konvencie z roku 1906 na návrh Haagskej konferencie z roku 1899 zablokované Vel'kou vojnou. Po vystúpení z nej sa zdalo, že situácia bola na mŕtvom bode s výnimkou Ženevskej konvencie o osude zajatcov z roku 1926. Po skúsenosti z druhej svetovej vojny dochádzalo k jednoznačnému pokroku ius in bello:

5 PRATT, Valéry. Juger la guerre : Nuremberg et la restauration de l'état de droit mondial. In AGLAN, Alya FRANK, Robert (ed.) 1937 - 1947. La guerre-monde, 2. Paris : Gallimard, 2015. 
Ženevské konvencie z 12. augusta 1949 išli omnoho d'alej v oblasti osudu ranených, zaobchádzania so zajatcami a ochrany civilného obyvatel'stva.

\section{Váha štátu, váha sociálnej otázky, nový sociálny štát}

Dva svetové konflikty zmenili štát v Európe a Amerike a jeho vztaha k hospodárstvu, ako aj k spoločnosti. Zasahovanie štátu do hospodárskych a sociálnych záležitostí sa výrazne posilnilo. Liberálne krédo laissez-faire a laissez passer (nechajte podnikaniu vol'ný priebeh) muselo urobit' ústupky realite vyplývajúcej z požiadaviek na mobilizáciu ludí, zdrojov, zariadení, zbraní, duší a myslí.

Bol tu však jeden rozdiel. V 20. rokoch európske krajiny nemali d'aleko od prijatia sloganu, ktorý republikánska strana použila v Spojených štátoch: Return to normalcy! ${ }^{6} \mathrm{~A}$ tento návrat $\mathrm{k}$ normálnosti bol najmä návratom $\mathrm{k}$ hospodárskemu liberalizmu bez bŕzd, bez regulácie, čo bezpochyby prispelo k prasknutiu finančnej bubliny a krachu Wall Street v októbri 1929, z čoho vyplynula svetová recesia v 30. rokoch. $V$ dôsledku nej osoby s rozhodovacou právomocou pripustili viac štátnych zásahov do hospodárstva: New Deal Franklina D. Roosevelta; britská politika opätovného ozbrojovania; hospodárska, sociálna politika a politika národnej obrany L’udového frontu; Keynesove nové myšlienky; pričom nepočítam skúsenosti so štátnymi zásahmi vo fašistickom Taliansku a nacistickom Nemecku.

S obnovením mieru po roku 1945 už prinajmenšom v Európe neexistoval tento reflex „návratu k normálnosti“ a návratu k čistému hospodárskemu liberalizmu. To bolo očividné vo východnej Európe, kde bol nastolený komunizmus. Platilo to však aj v liberálnej, demokratickej a kapitalistickej západnej Európe, ktorú prenasledoval strašiak roku 1929. Prevládli keynesiánske myšlienky. Prax išla niekedy ešte d’alej so znárodňovaním vo Vel'kej Británii a vo Francúzsku. Robilo sa všetko preto, aby „vystúpenie z vojny“ nevyústilo do svetovej hospodárskej krízy.

To isté platilo pre sociálnu politiku: štáty si zobrali ponaučenie z vystúpenia z prvej svetovej vojny. $\mathrm{V}$ tomto ohlade bol zaujímavý britský prípad. Aby vláda Lloyda Georgea udržala morálku na fronte a v zázemí počas Vel'kej vojny, prislúbila, že po vítazstve prijme reformy v prospech najchudobnejších. Ked’že v 20. rokoch tieto sl'uby neboli splnené, v rokoch 1939 až 1945 vládla v krajine ostražitost' a nedôvera. Vo Vel'kej Británii sa vojna vel'mi rýchlo začala nazývat' the people's war, akoby bolo potrebné, aby „l'ud“ po jej ukončení mal dobrú spomienku na vodcov. Nečudo, že Beveridgeova správa o sociálnom zabezpečení mala v roku 1942 taký úspech. Rovnako nečudo, že Winston Churchill, otec vítazstva, napriek svojej obrovskej popularite prehral vo vol'bách v júli 1945 proti labouristom: muž vojny sa nejavil ako muž, ktorý by v danej situácii dokázal reagovat' na túžby mierovej spoločnosti, vyvodit' dôsledky z tejto people's war a nedopustit' sa chýb 20. rokov. Labour Party po roku 1945 skutočne posilní Welfare State. To isté platí pre Francúzsko, kde dočasná vláda Francúzskej republiky pod vedením generála de Gaullea prijala mnohé myšlienky programu Národnej rady odboja, okrem iného

6 Prejav republikánskeho kandidáta na prezidenta Spojených štátov Warrena G. Hardinga 14. mája 1920. 
myšlienku vytvorenia sociálnej poistovne. Vystúpenie z vojny prinieslo mnohé sociálne zmeny aj inde v Európe: agrárne reformy vo východnej Európe spôsobia zánik vel'kostatkov a stáročných spoločenských tried, ktoré s nimi boli spojené: junkeri vo východnom Nemecku a magnáti v Mad’arsku.

Vystúpenie z vojny prostredníctvom európskej jednoty (20. roky a 40. - 50. roky)

Vystúpenia z dvoch vojen urobili z európskej jednoty aktuálnu tému. Prvé vystúpenie vojny bolo zásadné, lebo transformovalo starú „myšlienku Európy“ vyhradenú niekol'kým zriedkavým básnikom, prorokom a politikom na nové „európske vedomie“, t. j. na pocit nevyhnutnosti a naliehavosti (už to nie je len „myšlienka v ovzduší") spoločný pre široké hospodárske, intelektuálne a politické elity. $\mathrm{Na}$ tomto základe vznikli prvé „európske hnutia“ so siet’ami spájajúcimi podnikatelov, spisovatelov, mužov zo všetkých strán (s výnimkou krajnej pravice a krajnej l'avice). Tento pocit nevyhnutnosti dobre vyjadrila kniha Gastona Riou s naliehavým názvom Zjednotit'sa, alebo zomriet', ktorý spresnil hlavným motívom: ak sa Európa nedokáže zjednotit', bude druhá svetová vojna. Kniha bola napísaná v roku 1929. Vyústením tohto prvého európskeho vedomia založeného na dvoch naliehavých požiadavkách (mier a odmietanie úpadku Európy) bolo zblíženie medzi Gustavom Stresemannom a Aristidom Briandom, potom prejav Aristida Brianda v Spoločnosti národov 5. septembra 1929 a nakoniec Briandov plán Európskej federálnej únie z mája 1930. Tento plán nemal pokračovanie. A druhá svetová vojna naozaj vypukla.

Je pochopitel'né, že druhé vystúpenie z vojny prinieslo druhé európske vedomie a druhé európske hnutie založené na troch pilieroch, z ktorých dva boli rovnaké ako v 20. rokoch (túžba po mieri a posadnutost' úpadkom), a pridala sa k nim potreba demokracie. Európa, ktorá sa mala vybudovat', musela byt' demokratická: zatial' čo Briandov plán bol navrhnutý všetkým krajinám kontinentu (okrem ZSSR) vrátane pravicových autoritatívnych režimov a fašistického Talianska, demokracia bola po roku 1945 nevyhnutnou podmienkou vstupu do európskej organizácie, v dôsledku čoho bola európska jednota bez komunistickej Európy neúplná. Po mnohých peripetiách sa budovanie Európy skutočne začalo v roku 1950 so Schumanovou deklaráciou o Európe uhlia a ocele, ktorú akceptovalo šest' krajín. Francúzsko, ktorému sa v predchádzajúcich rokoch nepodarilo dohodnút' s britským spojencom na naštartovaní európskej jednoty, sa nakoniec dohodlo s bývalým nepriatelom, Nemcami, na spustení tejto iniciatívy: z tohto hladiska bol rok 1950 skutočne jedným z vystúpení z druhej svetovej vojny, či dokonca jedným z vystúpení z oboch svetových vojen súčasne: Schuman a Adenauer uspeli tam, kde Briand a Stresemann nechali dielo vo vel'kej miere nedokončené. ${ }^{7}$

7 FRANK, Robert - BOSSUAT, Gérard (ed.) Les identités européennes au XXe siècle : convergences, diversités et solidarités. Paris : Publications de la Sorbonne, 2004. 


\section{Osobitosti vystúpenia z druhej svetovej vojny}

Mnohé aspekty vystúpenia alebo vystúpení z druhej svetovej vojny majú črty, ktoré úzko súvisia s priebehom tohto konfliktu.

\section{Ničenie a utrpenie: znovu vybudovat' a napravit'}

Masa mŕtvych (okolo 60 miliónov, t. j. šest'krát viac ako v prvej svetovej vojne), padlí v boji, ale aj, čo je nevídanejšie, milióny mŕtvych civilov, rozsah ničivej sily mimoriadne „urbicídnej“ vojny s mestami úplne zdevastovanými bombardovaním, s prestáahovaným obyvatel'stvom, najmä počas tohto vel'kého európskeho malstrómu v roku 1945, bremeno hladu a nedostatku, to bol celý rad utrpení a tráum, ktoré v dovtedy nepoznanej miere poznačili Európu a východnú Áziu. Tieto skutočnosti sú príliš dobre známe na to, aby som ich tu rozvádzal.

Vystúpenie z vojny teda prebiehalo prostredníctvom fázy nápravy hmotných škôd, ktorá trvala prinajmenšom do začiatku 50. rokov. Čas nedostatku bol tiež dost' dlhý: napríklad prídelové lístky boli vo Francúzsku zrušené v roku 1949, vo Vel'kej Británii na začiatku 50. rokov. Týmito aspektmi sa zaoberá klasická historiografia „povojnového obdobia“. Problematika „vystúpení z vojny“ sa okrem toho zaujíma o váhu tohto utrpenia a tráum a o spôsob, akým dotknuté osoby vstúpili do mieru. Trvá to určitý čas, a teda datovanie už nie je úplne rovnaké ako datovanie „povojnového obdobia“. Vrátim sa k tomu, ked’ sa budem zaoberat' otázkou spomienok.

\section{Vystúpenie z nemeckej, talianskej a japonskej okupácie a vystúpenie z reži- mov, ktoré kolaborovali s okupantom}

„Okupácia“ bola rozšírenou skutočnost'ou v rokoch 1937 - 1945 rovnako ako kolaborácia s okupantom a nastolenie vlád, ktoré boli voči nemu zhovievavé. Okupácia sa skončila niekedy otvorenou občianskou vojnou (Juhoslávia, Čína) alebo často skrytou či len slovnou občianskou vojnou. Súdne a mimosúdne „čistky“ boli jedným z procesov tohto zúčtovania. Aj v tomto prípade dochádzalo k amnestiám odsúdených za „kolaboráciu“ či „zradu“ na začiatku 50. rokov.

S „vystúpením z vojny“ súvisela aj otázka postavenia odbojárov v spoločenskom a politickom živote v momente prechodu do mierového stavu. Mnohí síce mali dôležitú úlohu, „pokrokové“ myšlienky odboja boli síce zohladnené vo vel'kých reformách po roku 1945, nedá sa však povedat', že by sa dostávali k moci. „Hrdinovia" naháňali strach a návrat k mieru, k normálnosti si vyžadovalo skôr obyčajných mužov vzbudzujúcich dôveru. V západnej Európe znova vstúpili do politiky tradičné strany, často v zmenenej podobe, zatial' čo mnohí bývalí odbojári rezignovali. Na východe často, nie však vždy, vnútorných komunistických „odbojárov“ odsunú nabok alebo „eliminujú“ „ovplyvnení Moskvou“ (aktivisti, ktorí boli počas okupácie svojej krajiny v ZSSR): Gomułku odsunie Bierut v Pol'sku v roku 1948; Rajka „odstráni“ Rákosi v Mad’arsku v roku 1949; ${ }^{8}$ v Českosloven-

8 Rovnako vo Francúzsku Thorez proti Tillonovi a Martymu v roku 1952. Naopak, v Rumunsku v roku 1952 zvítází Gheorghiu-Dej, „odbojár“ uväznený počas vojny, nad židovkou Anou Paukerovou „ovplyvnenou 
sku v roku 1952 Gottwald „ovplyvnený Moskvou“ „odstráni“ Clementisa (počas vojny bol v Londýne), ale aj Slánského napriek tomu, že aj on bol ovplyvnený Moskvou prinajmenšom do roku 1944, ked' sa zúčastňoval na oslobodení Slovenska.

\section{Vystúpenie z druhej svetovej vojny: prvé „brutalizujúce“ vystúpenie?}

Po roku 1918 nad’alej panovala „kultúra vojny“ a brutalizácia stále vládla mysliam, čo spôsobilo krehkost' demokracií a umožnilo zrod troch totalít - fašizmu, komunizmu a nacizmu. ${ }^{9} \mathrm{U}$ istého Ernsta Jüngera dokonca pozorujeme estetizáciu vojny. Vel’ká vojna však priniesla aj opak, t. j. „kultúru mieru“ dostatočne živú na to, aby verejná mienka podporovala Spoločnost' národov aspoň dovtedy, kým neukázala svoje slabé stránky, a aby vznikli silné pacifistické hnutia 20. a 30. rokov. ${ }^{10}$ „Kultúra vojny“ a „kultúra mieru“ si skrátka v tomto období navzájom konkurovali. Po roku 1945 „kultúra mieru“ úplne zvít’azila nad „kultúrou vojny“. Dokonca aj Ernst Jünger, ktorý už uprednostňoval rozjímanie pred opojením z boja, sa stal mužom mieru a zmierenia medzi Francúzskom a Nemeckom.

Brutalizujúce vystúpenie bezpochyby nebolo úplné: komunizmus vychádzal z konfliktu posilnený, a hoci už nikto neoslavoval vojnové násilie, revolučné násilie obrátené dovnútra, a nie za hranice, malo stále svojich adeptov v Európe, Ázii, Afrike a Latinskej Amerike.

\section{Váha spomienok: začiatok vystúpenia z okupačných syndrómov až okolo roku 2000}

Spomienky na druhú svetovú vojnu sú omnoho komplexnejšie než spomienky na prvú. V oboch prípadoch sú ich súčastou spomienky na násilie. Spomienky na prvý konflikt sa však usilujú zjednotit' spoločnosti a národy v uctievaní mŕtvych; naopak, spomienky na druhý konflikt sa ich usilujú rozdelit' tam, kde vyčíňala nemecká, talianska a japonská okupácia.

Francúzsky prípad je dobre známy vd’aka „vichystickému syndrómu“,11 ktorý bol spojený najprv s obdobím potláčania vichystickej minulosti a kolaborácie s okupantom v rokoch 1955 - 1971 a potom s obdobím „návratu potláčaného“ v 70. rokoch, po ktorom nasledovalo obdobie „posadnutosti“ udalost'ami okupácie. „Vystúpenie zo syndrómu“ bolo vel'mi oneskorené a neúplné a nastane po roku 2000.

Všade v kontinentálnej Európe boli spomienky rozhárané, lebo bolo vel’mi t’ažké začlenit’ do národných príbehov epizódy kolaborácie a režimov, ktoré boli spoluvinníkmi alebo satelitmi hitlerovského Nemecka. Nové štáty vzniknuté po

\footnotetext{
Moskvou“, ktorá bola obvinená z „kozmopolitizmu“.

9 MOSSE, George. De la Grande Guerre au totalitarisme : la brutalisation des sociétés européennes. Paris : Hachette littératures, 1999.

10 GUIEU, Jean-Michel. Le rameau et le glaive : les militants français pour la Société des Nations. Paris : Presses de la Fondation nationale des sciences politiques, 2008.

11 ROUSSO, Henry. Le syndrome de Vichy, 1944 - 1987. Paris : Le Seuil, 1987; CONAN, Eric - ROUSSO, Henry. Vichy, un passé qui ne passe pas. Paris : Fayard, 1993.
} 
prvej svetovej vojne neunikli týmto spomienkovým nezhodám po druhom konflikte. Niesli svoj podiel viny na rozpade týchto štátov v 90. rokoch po inom „vystúpení", vystúpení komunizmu: Chorváti a Srbi na jednej strane a Česi a Slováci na druhej strane rozhodne nemali rovnaké spomienky na druhú svetovú vojnu.

Dnes Európska únia pozná tieto rozpory: 8. máj 1945, deň nemeckej kapitulácie, sa nepripomína všade. Tento dátum predstavuje koniec nacistickej nočnej mory pre väčšinu Európanov. Neplatí to však pre tri pobaltské štáty, Estónsko, Lotyšsko a Litvu, lebo tento deň im pripomína začiatok sovietskeho zlého sna.

\section{Vystúpenie $\mathrm{z}$ „vojny-sveta“}

Druhá svetová vojna bola svetovejšia ako prvá, lebo sa na nej zúčastnili rozsiahlejšie časti planéty. Navyše počas Vel'kej vojny bola vojna vo východnej Ázii úplne oddelená od vojen v Európe a od solúnskeho frontu, zatial' čo počas druhého konfliktu Spojené štáty od roku 1941 predstavovali spojovník medzi európskou vojnou a ázijskou vojnou, medzi bitkami v Atlantickom a Tichom oceáne. V rokoch 1914 až 1918 sa nakoniec svet vo vojne stotožnil s Európou a zapojil sa do bojov za európske otázky. Bojovníci, ktorí prišli z Afriky alebo Ázie, neboli plnohodnotnými aktérmi, natol'ko boli podriadení. Prizma koloniálnych impérií maskovala vnímanie sveta a udržiava Európu v centre. Prvá svetová vojna bola ešte vojna Európy-sveta, Európy, ktorá sama seba považovala za svet. Počas druhej svetovej vojny boli metropoly okrem Vel'kej Británie odrezané od svojich kolónií a prestíž kolonizátorov, ktorí boli v roku 1940 porazení, prudko klesala. Konflikt tentoraz vytvoril „svet sám osebe“, ktorého všetky časti boli prepojené a Európa bola len jednou častou tejto planetárnej pavučiny: najmä v kolóniách dochádzalo k uvedomovaniu si celého radu vecí. Vystúpenie z tejto vojny-sveta bolo teda poznačené určitou deuropeizáciou sveta, čo v nasledujúcich rokoch potvrdilo rozsiahle dekolonizačné hnutie.

\section{Interferencia medzi vystúpením z vojny-sveta a začiatkom studenej vojny}

\section{Zákon gigantov a bipolárny svet}

Vel'ké európske krajiny a Japonsko stratili postavenie vel'mocí v prospech dvoch gigantov, ktorí odteraz vo svete určovali zákon: Spojené štáty a ZSSR. ${ }^{12}$ Zmenil sa celý niekol'kostoročný medzinárodný systém: európsky systém v mnohých ohladoch pretrvával napriek tomu, že sa transformoval, už však nereguloval svetové dianie, ktoré bolo teraz v rukách dvoch supervel'mocí. Ich „vel'ké spojenectvo" nevydržalo; pokusy o kondomínium stroskotali a od roku 1947 stáli proti sebe v „studenej vojne“, čo sa prekrývalo s vystúpením z druhej svetovej vojny. Táto interferencia mala niekol'ko dôsledkov.

Nie je nič prekvapivé na tom, že Spojené štáty sa po druhej svetovej vojne stali supervel'mocou. Táto krajina už ako prvá priemyselná krajina od 90. rokov 19.

12 GIRAULT, René - FRANK, Robert - THOBIE, Jacques. La loi des géants, 1941 - 1964. Paris : Masson, 1993. 
storočia a líder vo finančnej a obchodnej oblasti po Vel'kej vojne začala proces hospodárskej a kultúrnej amerikanizácie. Po roku 1945 Američania prijali úlohu politického lídra, ktorú mohli alebo mali hrat’ už predtým. Skutočnou novinkou po vystúpení z vojny bol posun vpred sovietskej sily, ktorej vojenská prítomnost' v strednej a východnej Európe formovala v jej prospech vel’kú zónu vplyvu v tomto regióne. Prečo a ako sa táto obyčajná zóna zmenila na blok satelitných krajín? Bol to výsledok úmyselnej vôle Stalina, ktorá vysvetluje americké obavy a spôsobila rozchod dvoch vel'mocí? Vytváral si ZSSR d'alšie záruky v dôsledku pôsobenia rôznorodých strachov ${ }^{13}$ Diskusia je ešte otvorená, ale vystúpenie z druhej svetovej vojny a začiatok studenej vojny sa spojili do jedného prúdu, ktorý rozdelil Európu na dve časti a Nemecko na NSR a NDR. Vystúpenie z konfliktu rokov 1939 - 1945 trvalo aj po začiatku studenej vojny, a teda prebiehalo odlišne na východe a na západe. Ako som uviedol, západ sa vrátil k snu o európskej jednote z 20. rokov, aby sa pokúsil definitívne vymanit' zo stavu vojny. Uskutočňovat’ ho však začne len západná Európa a „inú Európu“ (podl’a výrazu Czesława Miłosza) ponechala sovietskej kontrole. ${ }^{14}$

Pokial' ide o právne a diplomatické hladisko, v Paríži boli vo februári 1947 podpísané mierové zmluvy s bývalými spojencami Nemecka (Taliansko, Fínsko, Madarsko, Rumunsko, Bulharsko) tesne pred vypuknutím studenej vojny. Tá však znemožnila takýto mier s Nemeckom. Postupimské dohody z augusta 1945 skutočne upravili postavenie tejto krajiny. Potvrdili štyri okupačné zóny a predpokladali jednotné Nemecko. V rokoch 1947 - 1948 sa však ukázalo, že to nebolo možné. Dohody dočasne stanovovali západnú hranicu na Odre a Nise, o ktorej chcel Západ znova rokovat’ pri prijímaní mierovej zmluvy. Tá však prijatá nebola v dôsledku americko-sovietskej konfrontácie. Dohody boli podpísané len medzi jednotlivými „Nemeckami“ a ich novými spojencami bud' na východe, alebo na západe. Až vd’aka Ostpolitik Willyho Brandta podpísalo NSR v rokoch 1970 až 1973 nie mierovú zmluvu, ale dvojstranné medzinárodné zmluvy, ktoré vyrovnávali účty druhej svetovej vojny s príslušnými najdôležitejšími komunistickými krajinami: ZSSR, NDR, Pol’skom a Československom. Záverečným aktom Helsinskej konferencie v roku 1975 sa stalo viacstranným jedno zo spoločných ustanovení týchto zmlúv, konkrétne „neporušitel'nost’ hraníc“ vrátane hranice na Odre a Nise: tridsat' rokov po konflikte sa konečne uzavrela dohoda, ktorou štáty súhlasili s tým, že nebudú pomocou sily menit' územné hranice, ktoré ním boli stanovené. Takto sa v prospech „uvol’nenia“ spustilo právne vystupovanie z druhej svetovej vojny.

\section{Druhé „brutalizujúce“ vystúpenie: 70. roky}

Sedemdesiate roky bezpochyby predstavujú dôležitý zvrat prinajmenšom v Európe. Hospodárska kríza, ktorá sa začala v rokoch 1973 - 1974, koniec „slávnych tridsiatich“ (30 rokov silného hospodárskeho rastu po 2. svetovej vojne), ná-

13 SOUTOU, Georges-Henri Soutou, La guerre de cinquante ans. Les relations Est-Ouest 1943 - 1990. Paris : Fayard, 2001.

14 MIŁOSZ, Czesław. Une Autre Europe. Paris : Gallimard, 1964. 
stup hromadnej nezamestnanosti v nasledujúcich desat'ročiach skoncuje s optimizmom, s vierou v budúcnost'. Táto kríza budúcnosti ovplyvnila marxizmus na západe i na východe dlho pred pádom komunizmu: počas niekol'kých rokov hospodárske neúspechy východoeurópskych režimov, opakujúce sa nepokoje v Pol'sku, „Solženicynov efekt", dostupné informácie o drámach čínskej kultúrnej revolúcie a o masakroch spáchaných Červenými kmérmi spôsobili úplnú diskreditáciu ideológií sl'ubujúcich „žiarivú budúcnost'“ za cenu údajne dočasného porušovania l'udských práv. Slogany, podla ktorých „účel svätí prostriedky“ a „ked' sa rúbe les, lietajú triesky“, sa stávali jednoducho neznesitel'nými. Mnoho aktivistov revolúcie sa transformovalo na aktivistov za l'udské práva, napríklad bývalý „l'avičiar“ Bernard Kouchner. „Vojnové násilie“ prestalo byt' legitímne po roku 1945 po odhalení Dachau a Osvienčimu; teraz prestalo byt' legitímne „revolučné násilie" po mediálnom a oneskorenom odhalení gulagov. Sedemdesiate roky boli skutočne definitívnym vystúpením, prinajmenšom v hlavách, tohto dlhého cyklu „brutalizácie“ spusteného dvoma svetovými vojnami.

\section{0: vyriešenie nemeckej otázky a právne vystúpenie z dvoch vojen: druhej svetovej vojny a studenej vojny}

Po páde Berlínskeho múru 9. novembra 1989 rýchlo prebehol proces zjednotenia Nemecka, ktorý sa zavŕšil 3. októbra 1990. Otázka, či boli nemecké hranice vrátane hranice na Odre a Nise len „neporušitel'né", ako stanovovali zmluvy z roku 1970, alebo či sa stanú „nedotknutel'nými“, bola vyriešená o niekol'ko týždňov skôr Moskovskou zmluvou z 12. septembra 1990. Táto „zmluva dva plus štyri“ podpísaná dvoma nemeckými vládami a štyrmi okupačnými vel'mocami, „zmluva o konečnom usporiadaní vo vzt'ahu k Nemecku“, stanovila, že hranice sú „konečné“. Uzatvorila diskusie a potvrdila právne vystúpenie z dvoch vojen súčasne, druhého svetového konfliktu a konfrontácie medzi východom a západom. ${ }^{15}$

Vojna rokov 1939 - 1945 mala rozličné „vystúpenia“ rozvrhnuté v rámci dlhého obdobia a prepletené s dynamikou konfliktov, ktoré ju obkolesovali - prvej svetovej vojny a studenej vojny. Spôsobila mimoriadne významné traumy, trvalé spory a syndrómy, ktoré je t'ažké upokojit'. Teraz na začiatku 21. storočia sa však spomienky na tento konflikt začínajú upokojovat’ a analýzy historikov $\mathrm{v}$ tomto smere sa zhodujú. Naopak, v poslednom čase proti sebe stoja rozličné historiografické interpretácie Vel'kej vojny, ${ }_{1}^{16}$ prinajmenšom vo Francúzsku, hoci nemala taký negatívny účinok na národné spomienky. Pokial' ide o vystúpenie z studenej vojny, nie je úplné, kedže po nej stále existujú stopy najmä v strednej

15 SOUTOU 2001.

16 Niektorí historici ukazujú, že vojaci „vydržali“ predovšetkým vd’aka „patriotickému súhlasu“: AUDOINROUZEAU, Stéphane - BECKER, Annette, 14 -18, retrouver la guerre. Paris : Gallimard, 2000. Naopak, iní kritizujú tento pojem „súhlas“ a radšej zdôrazňujú váhu „donútenia“ zo strany vojenských a civilných orgánov: ROUSSEAU, Frédéric. Guerre censurée : une histoire des combattants européens de 14-18. Paris : Seuil, 1999; CAZALS, Rémy. 1914 - 1918: oser penser, oser écrire. In Genèses, č. 46, marec 2002. 
a východnej Európe. Aký paradox: podarilo sa druhej svetovej vojne, vojne medzi dvoma vojnami, dnes ako jedinej vyrovnat' svoje účty napriek tomu, že bola brutálnejšia a zanechala hlbšie rozkoly?

Z francúzštiny preložila Kornélia Ševčíková

Cituj:

FRANK, Robert. Vystúpenia z druhej svetovej vojny. In Forum Historiae, 2018, roč. 12, č. 2, s. 74-85. ISSN 1337-6861.

$\cdots$

Robert Frank

Emeritný profesor

Université de Paris 1 Panthéon-Sorbonne

frank.robert9@gmail.com 